\section{Original Research}

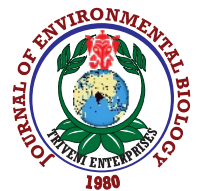

DOI : http://doi.org/10.22438/jeb/42/3(SI)/JEB-13
Journal website : www.jeb.co.in $\star$ E-mail : editor@jeb.co.in

\section{Journal of Environmental Biology} CODEN: JEBIDP
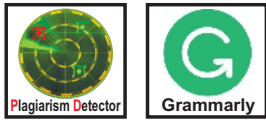

\title{
Macrobenthos diversity along the Exclusive Economic Zone of East Coast Peninsular Malaysia
}

\author{
B.B. Shafie', A. Man ${ }^{3}$, N.F. Ali ${ }^{1}$ and A.A. Rahim ${ }^{2 *}$ \\ 'Department of Earth Science and Environment, Faculty of Science and Technology, Universiti Kebangsaan Malaysia, Bangi, 43600, Malaysia. \\ ${ }^{2}$ Marine Ecosystem Research Centre (EKOMAR), Faculty of Science and Technology, Universiti Kebangsaan Malaysia, Bangi, 43600, Malaysia \\ ${ }^{3}$ Fisheries Research Institute (FRI), Kampung Acheh, Sitiawan, 32000, Malaysia \\ *Corresponding Author Email : abarahim@ukm.edu.my
}

\section{Abstract}

Aim: To examine the standing stock of macrobenthos along a depth gradient at regional scales in the Sunda Shelf of Malaysian Economic Exclusive Zone (EEZ).

Methodology: Macrobenthos was sampled with a Smith-Mclntyre grab at 19 stations on the continental shelf of the South-western South China Sea (east coast of Peninsular Malaysia) within the EEZ and was carried out onboard MV SEAFDEC II in May/June 2016.

Results: The faunal composition, abundance, and diversity of species, together with environmental parameters were studied. A total of 10,232 individuals comprising 105 families were identified. The dominant macrobenthic group was Mollusca (55.25\%), followed by Annelida (26.80\%) and Arthropoda (15.36\%), while the Echinodermata and Miscellaneous group recorded $1.13 \%$ and $1.43 \%$ respectively. Based on Bray-Curtis species similarities, five different sample groups (SGs) were distinguished, which were located in different zones and gradients of EEZ.

Interpretation: Variations in the macrobenthic community is significantly associated with depth, temperature, and salinity. Further research should be conducted on other factors that contribute to the diversity of macrobenthos along the east coast of Peninsular Malaysia's EEZ.

Key words: Macrobenthos, Peninsular Malaysia, South China Sea, Sunda Shelf

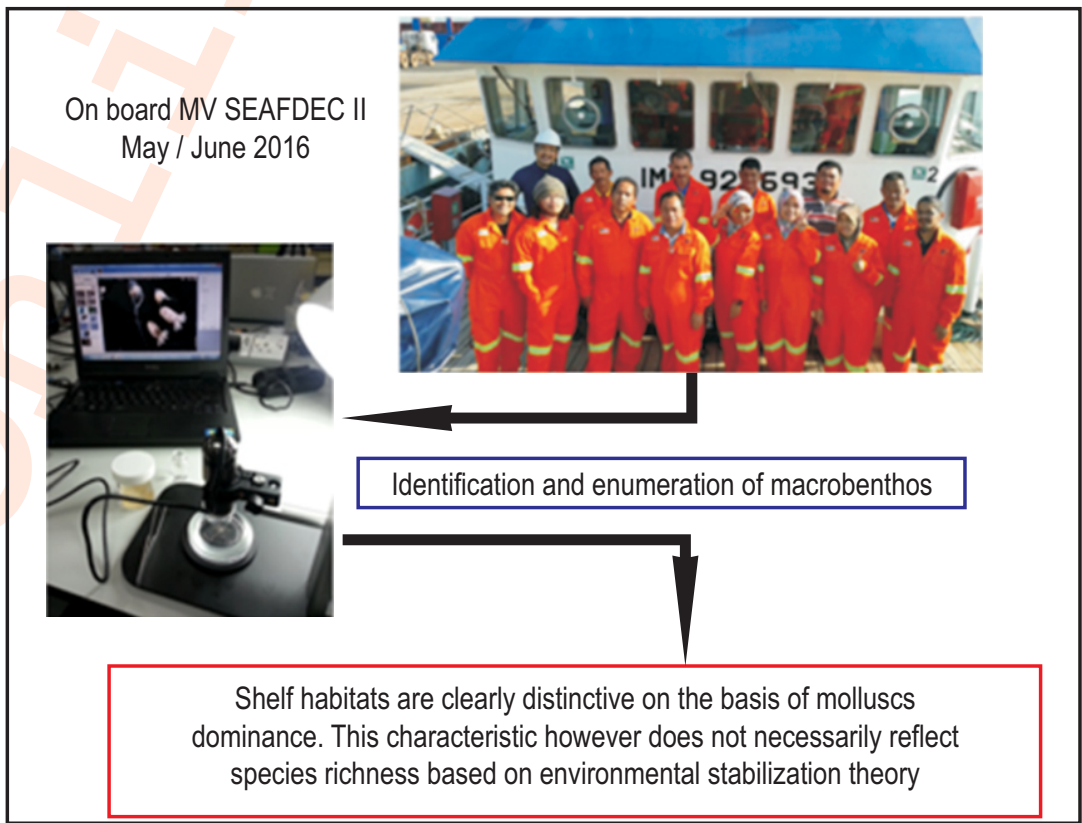

How to cite : Shafie, B.B., A. Man, N.F. Ali and A.A. Rahim: Macrobenthos diversity along the Exclusive Economic Zone of East Coast Peninsular Malaysia. J. Environ. Biol., 42, 817-823 (2021). 


\section{Introduction}

Malaysia comprises two major landmasses, Peninsular Malaysia and Sabah and Sarawak separated by 3 the Straits of Malacca, the Sulu Sea, and the southwestern part of South China Sea (Akhbar and Sohor, 2009; Mazlan et al., 2005). Exclusive Economic Zone of the east coast Peninsular Malaysia is located in the South China Sea, which is in the East Asian Ocean region that categorized as high diversity marine ecosystem with presence of Coral Triangle as the centre of tropical fauna and contains almost $76 \%$ of worldwide species (Albelda et al., 2020; Glasby et al., 2016; Hoeksema, 2007; Mazlan et al., 2005; Veron et al., 2009). On 25th April 1980, Malaysia had declared the Exclusive Economic Zone (EEZ) based on the 'new map Boundary Waters and continental shelf 1979' (RMN, 2007). The maritime jurisdiction in the area can be divided into territorial waters of about $35,900 \mathrm{~km}^{2}$ and EEZ waters of about $99,750 \mathrm{~km}^{2}$ (Ahmad et al., 2003). Within these ecosystems, different organisms interact with each other, where large-sized organisms dominate, but stabilized by the presence of small-sized organisms as a primary producer such as benthos (Ambrose, 1984; Dunn and Hovel, 2020).

Benthic community characterisation of Malaysian waters lacks in general, and off the east coast peninsular Malaysia in particular. The EEZ water has many characteristic features in its oceanography, although it is relatively flat with a maximum depth of $80 \mathrm{~m}$ (Ahmad et al., 2003). Channelization of numerous rivers and streams makes the coastal perimeter of east coast of Peninsular Malaysia a unique biological habitat. These coastal habitat show high marine biodiversity and are unique with regard to flora and fauna of the Malaysian continental shelf. Benthic community composition studies in Malaysia have reported high biological productivity and rich biodiversity of this habitat that is also an important component in the trophic dynamics (Ambrose, 1984; Wan-Lotfi, 1995). Although they are small in size with limited mobility, macrobenthos plays an important role as an environmental indicator as they are more exposed to pollution (Dean, 2008; Lipi et al., 2020; Yasin and Razak, 1999). Macrobenthos provides rapid response to any physical and chemical environmental change. Any fluctuations in quality and quantity of macrobenthos diversity can act as a reference point for water quality and this could impinge maritime countries that utilise their marine resources (fishing) as national economic means (Piamthipmanus 1999).

\section{Materials and Methods}

This study was conducted within the Exclusive Economic Zone (EEZ) along the east coast Peninsular Malaysia. Sediment samples were collected onboard MV SEAFDEC II at 19 stations at the depth range of $20-80 \mathrm{~m}$ on the Sunda shelf (Fig. 1). Temperature and salinity data were collected with a YSI CTD Cast Away and multi-parameter prob 'ALEC AAQ-1183'.

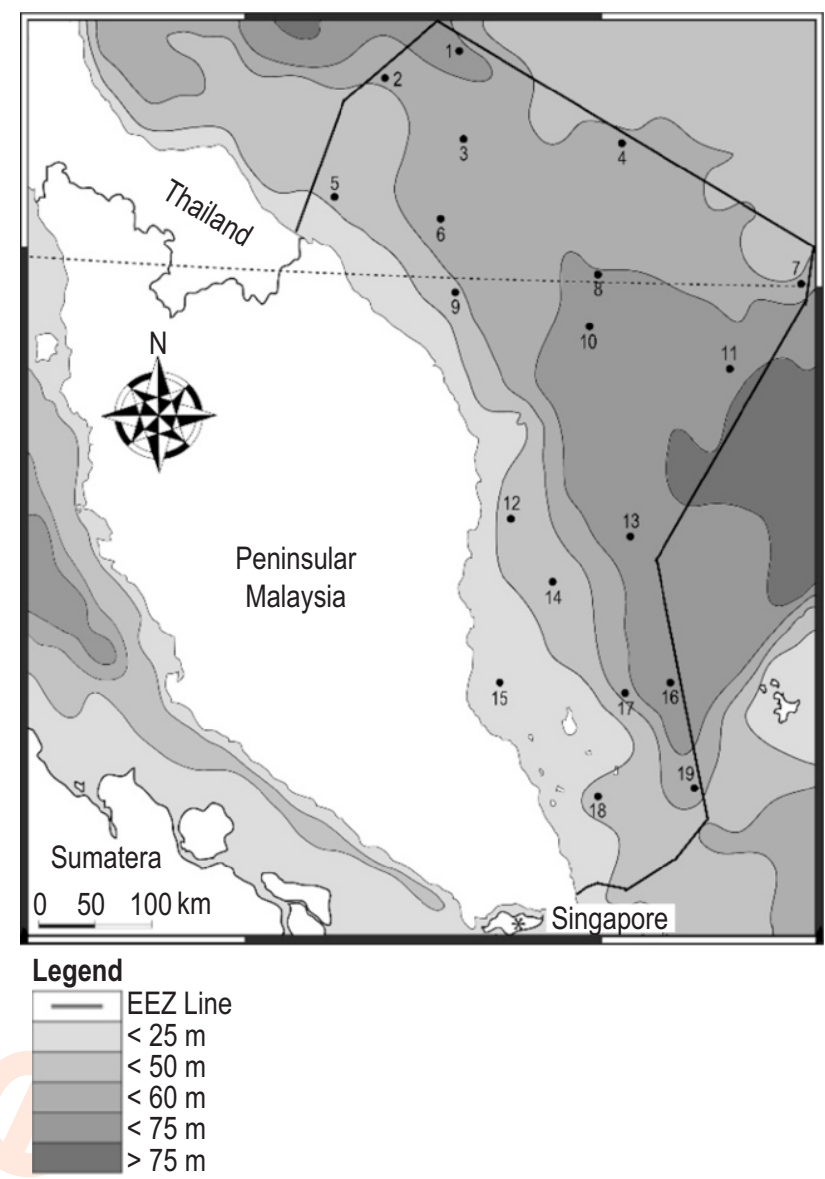

Fig. 1 : Sampling stations in the Exclusive Economic Zone of Peninsular Malaysia

Macrobenthos samples were collected with Smith Mclntyre (0.05 $\mathrm{m}^{2}$ ). Samples were sieved with $1.0 \mathrm{~mm}$ and $0.5 \mathrm{~mm}$ mesh and preserved in $10 \%$ formalin solution in seawater and transferred to Universiti Kebangsaan Malaysia (UKM) laboratory for further analysis. Macrobenthos were sorted and identified to the lowest taxonomic level with the help of references (Barnard, 1961; Barnard and Karaman, 1991; Dame, 2011; Fauchald, 1977). Analysis of the population was carried out using Paleontological Statistics (PAST 3.20) to calculate diversity indices. Similarities between sampling stations were observed by using Bray-Curtis clustering. At the same time, Spearman correlation tests were performed to find the relationships between biotic and abiotic factors.

\section{Results and Discussion}

A total of 10,232 macrobenthos individuals comprising 105 families were successfully identified. In the present study, the diversity of macrobenthos was in the sequence of Mollusca $(55.25 \%)$, followed by Annelida $(26.80 \%)$ and Arthropoda $(15.36 \%)$ while Echinodermata and Miscellaneous group recorded $1.13 \%$ and $1.43 \%$, respectively. The highest abundance 
Table 1 : Environmental variables and diversity indices value

\begin{tabular}{llllll}
\hline Station & Depth $(\mathrm{m})$ & Temperature $\left({ }^{\circ} \mathbf{C}\right)$ & Salinity $(\mathbf{p p t})$ & Diversity $\left(\mathbf{H}^{\prime}\right)$ & Abundance $(\mathrm{Dmg})$ \\
\hline 1 & 62.55 & 28.16 & 33.57 & $3.17 \pm 0.16$ & $7.19 \pm 0.38$ \\
2 & 56.00 & 29.15 & 33.07 & $2.87 \pm 0.06$ & $5.30 \pm 0.22$ \\
3 & 55.03 & 28.20 & 33.39 & $3.02 \pm 0.02$ & $6.41 \pm 0.00$ \\
4 & 58.41 & 28.24 & 33.6 & $2.88 \pm 0.20$ & $6.31 \pm 0.54$ \\
5 & 30.07 & 31.36 & 33.16 & $3.15 \pm 0.09$ & $7.86 \pm 0.21$ \\
6 & 55.00 & 28.82 & 33.43 & $2.97 \pm 0.02$ & $7.07 \pm 0.87$ \\
7 & 57.11 & 26.30 & 33.77 & $3.09 \pm 0.10$ & $7.08 \pm 0.17$ \\
8 & 61.30 & 25.23 & 33.81 & $2.99 \pm 0.07$ & $6.61 \pm 0.61$ \\
9 & 5.02 & 28.87 & 33.58 & $3.34 \pm 0.00$ & $8.20 \pm 0.36$ \\
10 & 71.05 & 25.06 & 33.77 & $2.74 \pm 0.06$ & $5.79 \pm 0.55$ \\
11 & 62.39 & 25.34 & 33.83 & $2.59 \pm 0.01$ & $4.29 \pm 0.22$ \\
12 & 38.00 & 25.34 & 33.77 & $2.84 \pm 0.08$ & $7.18 \pm 1.15$ \\
13 & 67.97 & 23.92 & 34.08 & $2.10 \pm 0.34$ & $7.22 \pm 0.14$ \\
14 & 43.43 & 25.37 & 33.83 & $3.17 \pm 0.01$ & $7.75 \pm 0.28$ \\
15 & 21.03 & 29.02 & 33.36 & $3.23 \pm 0.02$ & $7.07 \pm 0.68$ \\
16 & 68.11 & 23.76 & 34.11 & $1.41 \pm 0.14$ & $3.78 \pm 0.24$ \\
17 & 46.63 & 25.26 & 33.83 & $3.34 \pm 0.09$ & $8.75 \pm 0.13$ \\
18 & 33.95 & 28.91 & 33.45 & $3.53 \pm 0.06$ & $9.04 \pm 0.10$ \\
19 & 51.65 & 26.11 & 33.75 & $3.29 \pm 0.01$ & $7.81 \pm 0.14$ \\
\hline
\end{tabular}

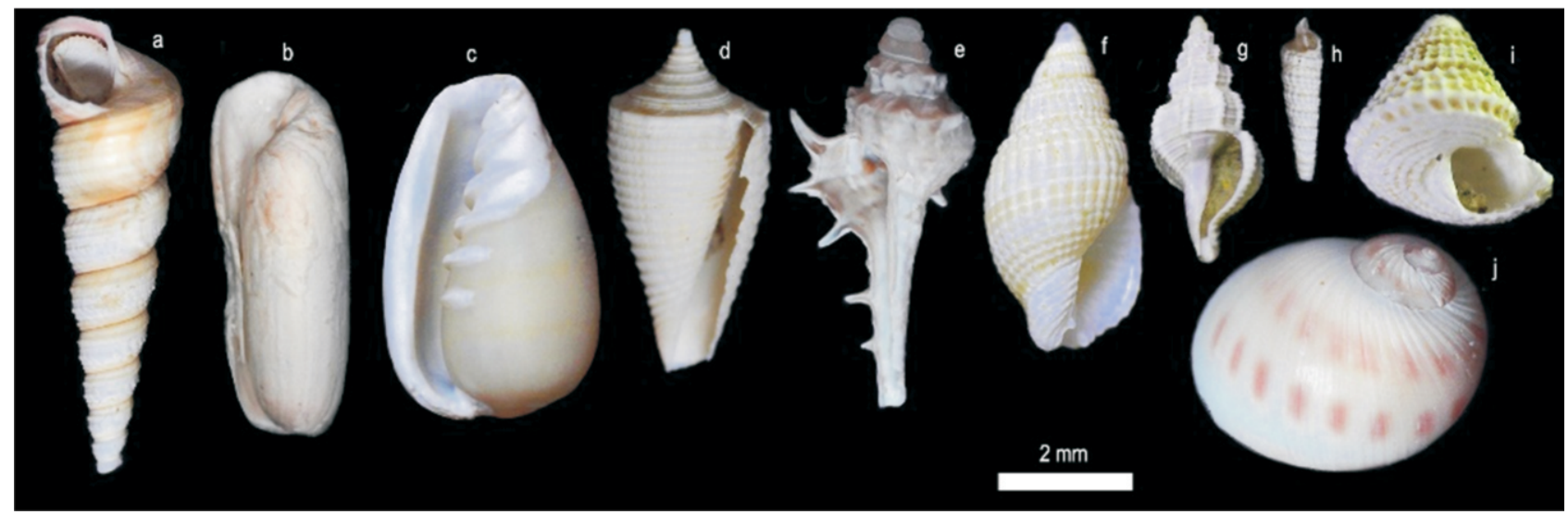

Fig. 2 : Some gastropod families collected at Peninsular Malaysian EEZ. (a) Turitellidae (b) Haminoeidae (c) Cypraeidae (d) Conidae (e) Muricidae (f) Buccinidae sp.1 (g) Buccinidae sp.2 (h) Pyramidellidae (i) Turbinidae (j) Naticidae.

was observed at $34 \mathrm{~m}$ depth $(9.04 \pm 0.10)$ and the lowest at $24 \mathrm{~m}$ depth (3.78 \pm 0.24$)$. Macrobenthos diversity was recorded highest at station $18\left(\mathrm{H}^{\prime}=3.53 \pm 0.06\right)$ while, and station 16 had the lowest value with $H^{\prime}=1.41 \pm 0.14$ (Table 1).

Generally, in this study molluscs dominated the macrobenthic population. A total of 16 mollusc families were encountered, of which Gastropoda comprised 15 families and Bivalvia 1 (Fig. 2). Of the 15 gastropod families, Buccinidae (2,406 individuals) and Haminoeidae (1,059 individuals) were dominant. On the other hand, bivalves (Solenidae) only recorded 7 individuals. The second highest class recorded was Polychaeta (2,743 individuals), which consisted a total of 35 families. Among sedentarian families, Capitellidae contributed the maximum (515 individuals), followed by Spionidae (392 ind) (Fig. 3). Among the crustaceans, amphipods (19 families) constituted the largest number (Fig. 4), followed by Decapods (9 families), Isopods ( 3 families) and Tanaids ( 3 families). Melitidae (802 ind) and Ampeliscidae (174 ind) were the major families in Amphipoda. Other important families among amphipods were Photidae, Ischyroceridae, Dexaminidae, and Amphilocidae. Others were sparsely represented, forming only less than $3 \%$ of the total population composed of Echinoderms (Fig. 5), Sipuncula and Platyhelminthes.

According to Rol et al. (2013), an ecosystem rich in species diversity have high $\mathrm{H}^{\prime}$ value and low species diversity with low H' value. In comparison with other studies from the adjacent waters, Johor Strait, in particular, diversity index value in this study was relatively low since Johor Strait is generally regarded 


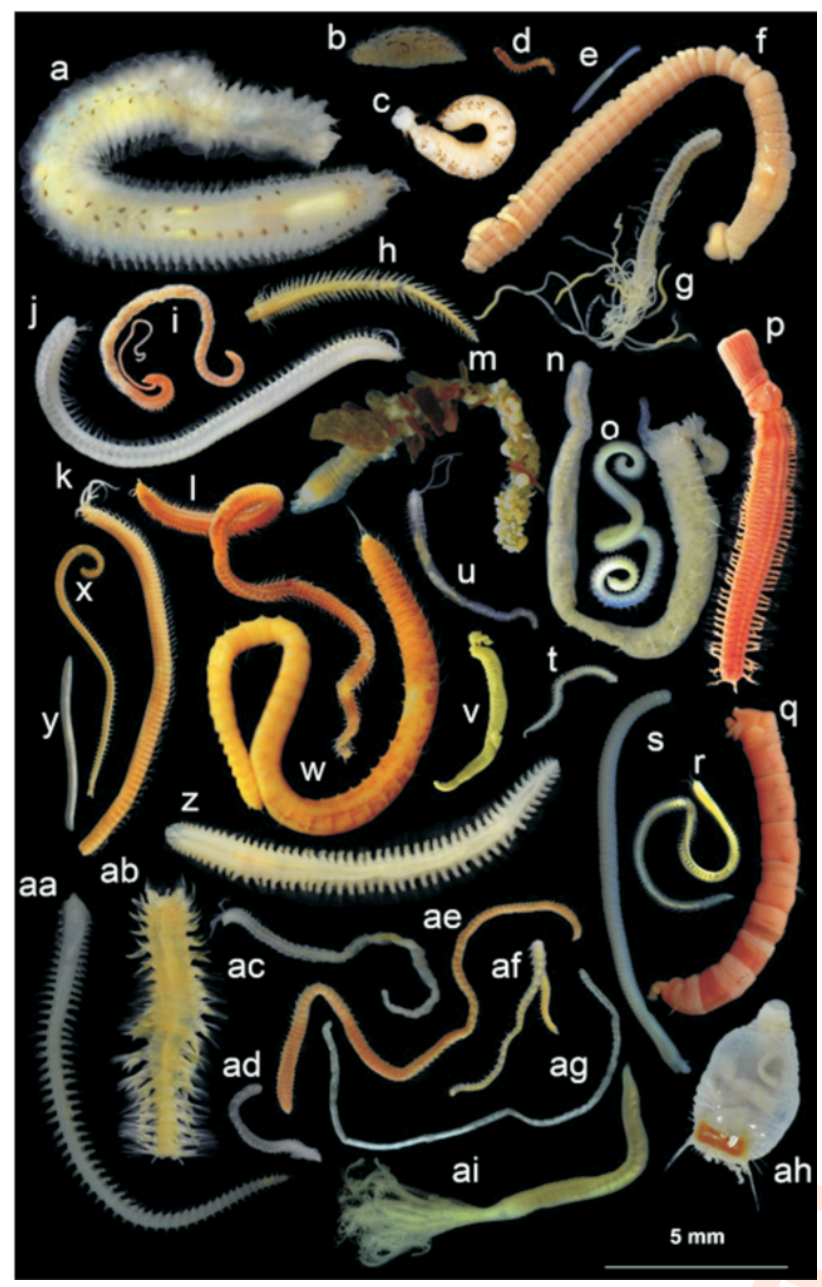

Fig. 3 : Some annelid families collected at Peninsular Malaysian EEZ. (a) Alciopidae (b) Amphinomidae (c) Arenicolidae (d) Pilargiidae (e) Serpulidae (f) Capitellidae (g) Cirratulidae (h) Hesionidae (i) Cossuridae (j) Eunicidae (k) Onuphidae (I) Dorvilleidae (m) Ampharetidae (n) Chaetopteridae (o) Paraonidae (p) Glyceridae (q) Maldanidae ( $r$ ) Polynoidae (s) Lumbrinereidae (t) Phyllodocidae (u) Aspidobranchidae (v) Terebellidae (w) Flabelligeridae (x) Gonianidae (y) Opheliidae (z) Nepthyidae (aa) Nereidae (ab) Poecilochaetidae (ac) Spionidae (ad) Scallebregmidae (ae) Orbinidae (af) Syllidae (ag) Oweniidae (ah) Sternaspidae (ai) Sabellidae.

as multifaceted ecological areas due to the presence of estuaries and mangrove swamps (Wan-Lotfi et al., 2013).

The results of this study showed that the shelf habitats were distinctive on the basis of molluscs dominance. This characteristic, however, does not necessarily reflect species richness based on environmental stabilization theory because of high domination at the sampling stations by Buccinidae and Haminoeidae (Sanders, 1968). A study by Miloslavich et al. (2013) stated that gastropod abundance in an area could be described as a biodiversity hotspot or possibility of disturbances in the food chain due to gastropod dominance in competition for

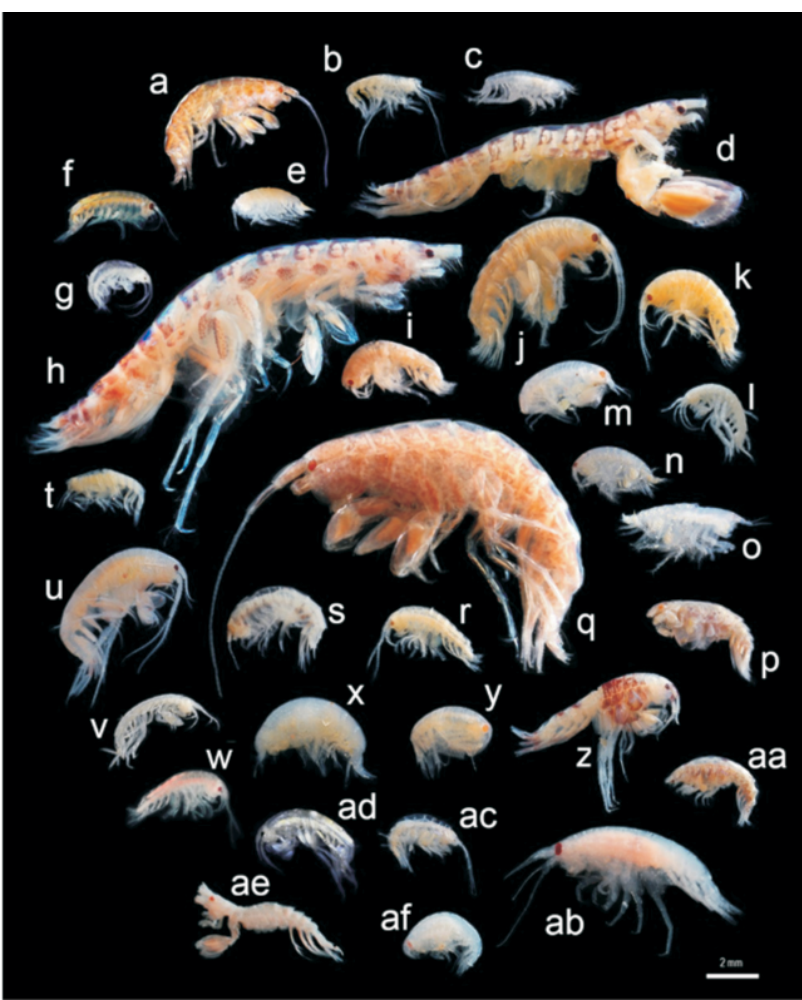

Fig. 4 : Some amphipods collected at Peninsular Malaysian EEZ. (a) Photidae (b) Oedicerotidae (c) Phoxocephalidae (d) Ischyroceridae (e) Urothoidae (f) Dexaminidae (g) Ischyroceridae (h) Melitidae (i) Cymadusa sp. (j) Ceradocus sp.1 (k) Cerodocus sp.2 (I) Melitidae (m) Amphilocidae (n) Urothoidae (o) Lysiannasidae (p) Podoceridae (q) Photidae (r) Elasmopus sp.1 (s) Dexaminidae (t) Oedicerotidae (u) Liljeborgidae (v) Melitidae (w) Elasmopus sp.2 (x) Amphilocidae (y) Cyprodidae (z) Liljeborgidae (aa) Podoceridae (ab) Lysiannasidae (ac) Elasmopus sp.3 (ad) Liljeborgidae (ae) Podoceridae (af)Amphilocidae.

food. Buccinidae is also dominant in the Arctic and Antarctic, while Haminoeida has been often recorded in both temperate and tropical regions at a shallow depth of less than $15 \mathrm{~m}$ but rarely in deep-sea (Bouchet and Waren, 1986; Oskars et al., 2017; Too et al., 2014; Zhang and Zhang, 2018). This can be explained by the ocean currents during Southwest Monsoon that transport macrosized gastropod individuals from shallow to deeper sea (Daryabor, 2014).

Another noticeable feature is the abundance of crustaceans like Elasmopus from the family Melitidae. Melitid amphipods have high genus diversity in tropical waters as well as Ampelisca, which is tantamount as benthic amphipod and can be found widely in Malaysian waters (Othman and Azman, 2007). Abundance of amphipod also can be influenced by ocean temperature due to heat flow (Lyubina et al., 2012) during the Southwest Monsoon. The ocean currents are characterized by the movement of hot water moving southward towards the east coast region (Akhir, 2014). 


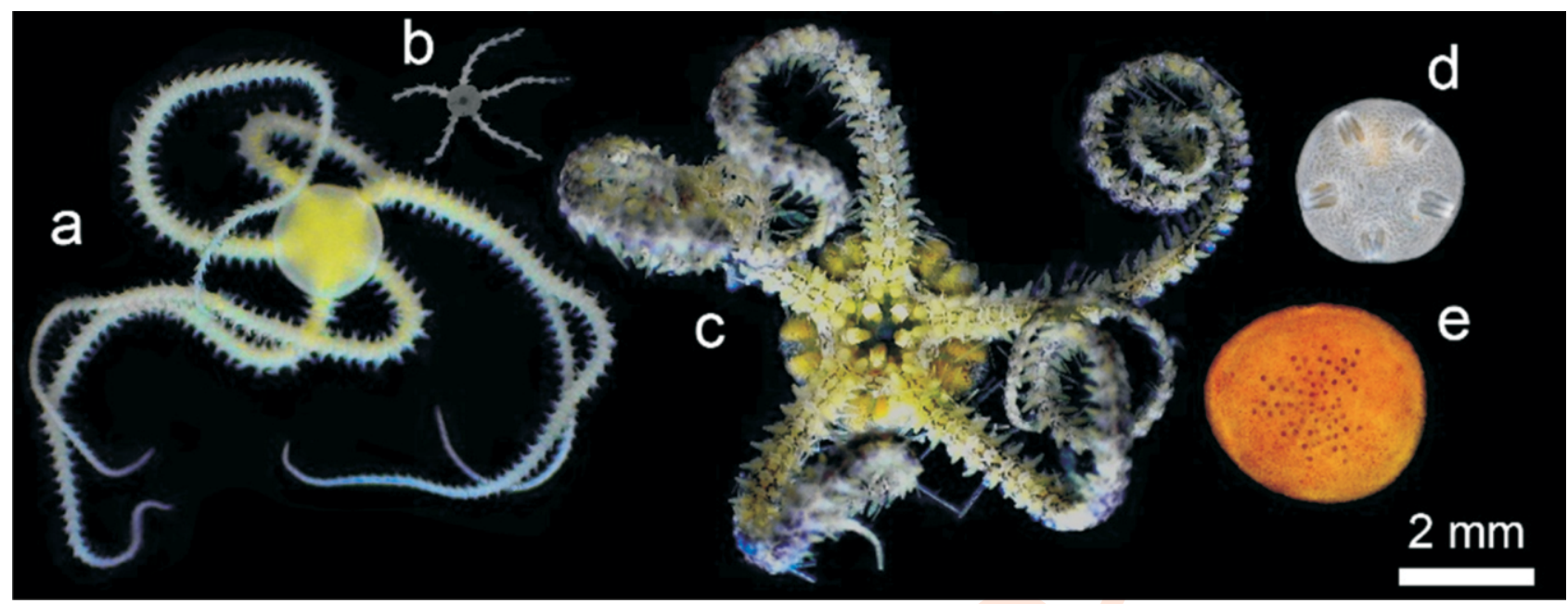

Fig. 5 : Some echinoderms collected at Peninsular Malaysian EEZ. (a) Amphiuridae (b) Juvenille Amphiuridae (c) Ophiacanthidae (d) Echinarachnidae (e) Temnopleuridae.

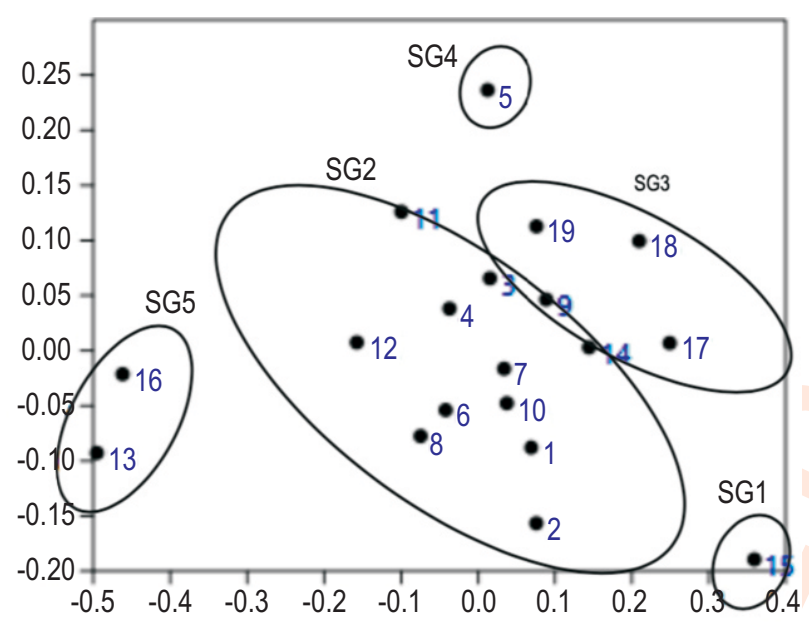

Fig. 6 : MDS configuration for stations on the basis of faunal density.

According to hypothesis of environmental stabilization by Sanders (1968), stable habitat (with constant temperature, salinity, dissolved oxygen) would likely stipulate high diversity.However, there are several abiotic influences that regulate the distribution and abundance of macrobenthic community, such as depth, current flow and temperature (Pearson, 1978). Based on Spearman's correlation analysis, depth, salinity, and temperature showed a significant value with each other $(p<0.05)$ (Table 2$)$, but depth was also correlated $(p<$ 0.05 ) with macrobenthos assemblages (Table 3). Macrobenthos distribution in tropical water is influenced by rainfall or monsoon, which may reduce salinity (Alongi, 1990; Montague and Ley, 1993). However, Grassle (1989) stated that depth and distance from shore highly affect the macrobenthos abundance as high macrobenthos abundance usually at depth $<60 \mathrm{~m}$ also primary production decreased with depth and phytoplankton is a major
Table 2 : Spearman correlation value between abiotic parameters ( $p$ value)

\begin{tabular}{llll}
\hline & Depth $(\mathrm{m})$ & Temperature $\left({ }^{\circ} \mathrm{C}\right)$ & Salinity (PSU) \\
\hline Depth $(\mathrm{m})$ & & & \\
Temperature $\left({ }^{\circ} \mathrm{C}\right)$ & 0.0076 & & \\
Salinity (PSU) & 0.0366 & 0.0001 & \\
\hline
\end{tabular}

Table 3 : Spearman correlation between biotic and abiotic factors $(p-$ value)

\begin{tabular}{llll}
\hline & $\begin{array}{l}\text { Individual } \\
\text { abundance }\end{array}$ & $\begin{array}{l}\text { No. of } \\
\text { families }\end{array}$ & $\begin{array}{l}\text { Diversity } \\
\text { index }\end{array}$ \\
\hline Depth $(\mathrm{m})$ & 0.1705 & 0.0488 & 0.0040 \\
Temperature $\left({ }^{\circ} \mathrm{C}\right)$ & 0.2057 & 0.4448 & 0.0309 \\
Salinity (PSU) & 0.1404 & 0.9783 & 0.1238 \\
\hline
\end{tabular}

contributor to detritus in benthic organisms (Burlakova et al., 2018; Nyabakken, 2001).

Based on the MDS analysis, five different sample groups were distinguished (Fig. 6). Sample groups were categorized mainly on the basis of depth, salinity and temperature. Among the nineteen stations SGs, SG1 and SG4 both consisted of only 1 station with depth less than $30 \mathrm{~m}$ and located nearest to the shoreline. Clustered stations (SG1 and SG4) recorded the lowest mean density of 7440 ind. $\mathrm{m}^{-3}$. SG3 and SG5 consisted of six stations (Fig. 6) of intermediate depths and having similar abiotic attributes with a mean density of 13100 ind. $\mathrm{m}^{-3}$. SG2 was the largest, consisting of eleven stations with a mean density of 10106 ind. $\mathrm{m}^{-3}$. Extensive abiotic attributes and relatively similar evenness index were the characteristic features of this SG. 
Based on the findings of this study, the interrelation between macrobenthos diversity and abiotic factors (temperature, salinity, depth) is important. Although abiotic attributes observed in this study do not provide a strong explanation for the distribution and abundance of macrobenthos, we believe that there is still sufficient information to conclude which of the many possible physical and biological factors drives them. Therefore, further study should be conducted to obtain more information and explanations followed by statistical evidence on macrobenthos diversity in EZZ of east coast Peninsular Malaysia for economical and academical uses.

\section{Acknowledgments}

Appreciation is extended to the Department of Fisheries Malaysia, Ministry of Agriculture and Food Industry for this cruise invitation using MV SEAFDEC II vessels. We gratefully acknowledge the members of cruise Mr. Sayan Promjinda, Mr. Narong Ruangsivakul and Ms. Pontipa Luadnakrop for sample collection. This work was supported by the Ministry of Education (Malaysia) under the Fundamental Research Grant Scheme (FRGS/1/2019/WAB13/UKM/02/3).

\section{Add-on Information}

\section{Authors' contribution: B.B. Shafie: Analyzed}

$\mathrm{th}$ e data,authored or reviewed drafts of the paper, and approved the final daft; A. Man:cruiseleader, reviewed drafts of the $p$ a $p$ e r, funding acquisition and approved the final draft; N.F. Ali: fields ampling, analyzed the data, authored or reviewed drafts of the paper, and approved the final draft; A.A. Rahim: conceived and designed the study, field sampling, analyzed the data, prepared figures and/ortables, authored or reviewed drafts of the paper and approved the final draft.

Research content: The research content is original and has not been published elsewhere

\section{Ethical approval: NotApplicable}

Conflict of interest: The authors declare that there is no conflict of interest.

\section{Data from other sources: NotApplicable}

Consent to publish: All authors agree to publish the paper in Journal of Environmental Biology.

\section{References}

Ahmad, A.T., M.M. Isa, M.S. Ismail and S. Yusof: Status of demersal fishery resources of Malaysia. In: Assessment, Management and Future Directions for Coastal Fisheries in Asian Countries (Eds.: G. Silvestre, L. Garces, I. Stobutzki, M. Ahmed, R.A. ValmonteSantos, C. Luna, L. Lachica-Alino, P. Munro, V. Christensen and D. Pauly). WorldFish Center Conference Proceedings, pp. 83-136 (2003).
Akhbar, A.A.K. and N.D. Sohor: Analisis faktor yang mempengaruhi hasil tangkapan ikan: kajian kes di perairan Sabak Bernam, Selangor. Prosiding Persidangan Kebangsaan Ekonomi Malaysia (PERKEM IV), 1, 286-304 (2009).

Akhir, M.F.: Review of current circulation studies in the southern South China Sea. J. Sustain. Sci. Manag., 9, 21-30 (2014).

Albelda, R.L., P.C. Cabaitan, F.P. Sinniger, E.D. Jr., T.J.R. Quimpo, R. Dionnie, D. Olavides, J.C. Munar, C. Villanoy and F.P. Siringan: Juvenile scleractinian assemblage and its association with adults and benthos at shallow and upper mesophotic depths in fringing and atoll reefs in the Philipines. Reg. Stud. Mar. Sci., 40, 1-44 (2020).

Alongi, D.M.: The ecology of tropical soft-bottom benthic ecosystems. Oceanogr. Mar. Biol. Annual Review, 28, 381-496 (1990).

Ambrose Jr, W.G.: Role of predatory infauna in structuring marine softbottom communities. Mar. Ecol. Prog. Ser., 17, 109-115(1984).

Barnard, J.L.: Gammaridean amphipoda. Galathea Rep., 5, 128 (1961).

Barnard, J.L. and G.S. Karaman: The families and genera of marine gammaridean amphipoda (except marine gammaroids): Part 2. Rec. Aust. Mus., 13, 419-866 (1991).

Bouchet, P. and A. Warén: Mollusca gastropoda: Taxanomical notes in tropical deep water Buccinidae with descriptions of new taxa. Mém. Mus. Natl. Hist. Nat., Sér. AZool., 133, 457-499 (1986).

Burlakova, L.E., R.P. Barbiero, A.Y. Karatayev, S.E. Daniel, E.K. Hinchey and G.J. Warren: The benthic community of the Laurentian Great Lakes: Analysis of spatial gradients and temporal trends from 1998-2014. J. Great Lakes Res., 44, 600-617 (2018).

Daryabor, F.: Simulation of southwest monsoon current circulation and temperature in the east coast of Peninsular Malaysia. Sains Malays., 43, 389-398 (2014).

Dame, R.F.: Ecology of Marine Bivalves: An Ecosystem Approach. $2^{\text {nd }}$ Edn., CRC Press, Boca Raton, Florida, USA(2011).

Dean, H.K.: The use of polychaetes (Annelida) as indicator species of marine pollution: Areview. Rev. Biol. Trop., 56, 11-38 (2008).

Dunn, R.P. and K.A. Hovel: Predator type influences the frequency of functional responses to prey in marine habitats. Biol. Lett., 16, 1-8 (2020).

Fauchald, K.: The polychaete worms. Definitions and keys to the orders, families and genera. Natural History Museum of Los Angeles County, 28, 1-188(1977).

Glasby, C.J., Y.L. Lee and P.W. Hsueh: Marine Annelida (excluding cilitellates and siboglinids) from the South China Sea. Raffles Bull. Zool., 34, 178-234 (2016).

Grassle, J.F.: Species diversity in deep-sea communities. Trends Ecol. Evol., 4, 12-15(1989).

Hoeksema, B.W.: Delineation of the Indo-Malayan centre of maximum marine biodiversity: The coral triangle. In: Biogeography, Time and Place: Distributions, Barriers, and Islands (Eds.: W. Renema). Springer, Dordrecht, p. 117 (2007).

Lipi, J.A., M.A. Noman, M.B. Hossain, H.M.K. Abu and H.I. Mohd: Effects of ship-breaking activities on the abundance and diversity of macrobenthos in Sitakundu Coast, Bangladesh. Biodiversitas, 21, 5085-5093 (2020).

Lyubina, O.S., O.L. Zimina and N.A. Anisimova: Distribution and variation of the amphipod fauna (crustacea, amphipoda) in the Kola Section (Barents Sea). Dokl. Biol. Sci., 442, 27-30 (2012).

Mazlan, A.G., C.C. Zaidi, W.M. Wan-Lotfi and B.H.R. Othman: On the current status of coastal marine biodiversity in Malaysia. Indian $\mathrm{J}$. Mar. Sci., 34, 76-87 (2005). 
Miloslavich, P., J.J. Cruz-Motta, E. Klein, K. Iken, V. Weinberger, B. Konar, T. Trott, G. Pohle, G. Bigatti, L. Benedetti-Cecchi and Y. Shirayama: Large scale spatial distribution patterns of gastropod assemblages in rocky shores. PLoS ONE, 8, 71-76 (2013).

Montague, C.L. and J.A. Ley: A possible effect of salinity fluctuation on abundance of benthic vegetation and associated fauna in northeaster Florida Bay. Estuaries Coast, 16, 703-717 (1993).

Nyabakken, J.W.: Marine Biology: An Ecological Approach. $5^{\text {th }}$ Edn., Benjamin Cummings, San Francisco, California, USA(2001).

Oskars, T.R., M. Constantine and M.A.E. Malaquias: Redescription of Atys jeffreysi (Weinkauff, 1866) (Haminoeidae), with a discussion on the phylogenetic affinities of the Mediterranean species of the genus. J. Nat. Hist., 51, 1-16 (2017).

Othman, B.H.R. and B.A.R. Azman: A new species of Talitridae (amphipoda: Gammaridae) from Tioman Island, Malaysia. Zootaxa, 1454, 59-68 (2007).

Piamthipmanus, M.: Temporal changes in the abundance of macrobenthos in the South China Sea, Area I: Gulf of Thailand and east coast of Peninsular of Malaysia. In: Proceedings of the First Technical Seminar on Marine Fishery Resources Survey in the South China Sea, Area I: Gulf of Thailand and Peninsular Malaysia. SEAFDEC Training Department, Samutprakan, Thailand, pp. 156-171 (1999).

Pearson, T.H. and R. Rosenberg: Macrobenthic succession in relation to organism enrichment and pollution of the marine environment. Oceanogr. Mar. Biol. Annual Review, 16, 229-311 (1978).

Rol, N., E. Enow and E. Bechem: Species composition, diversity and distribution in a distributed Takamanda Rainforest, South West,
Cameroon. Afr. J. Plant Sci., 7, 577-585 (2013).

Sanders, H.L.: Marine benthic diversity: A comparative study. Am. Nat., 102, 243-262 (1968).

Too, C.C., C. Carlson, P.J. Hoff and M.A.E. Malaquias: Diversity and systematics of Haminoeidae gastropods (Heterobranchia: Cephalaspidae) in the tropical West Pacific Ocean: New data on the genra Aliculastrum, Atys, Diniatys and Liloa. Zootaxa, 3, 355$392(2014)$

Veron, J.E.N., L.M. Daventier, E. Turak, A.L. Green, S. Kininmonth, M. Stafford-Smith and N. Peterson: Delineating the coral triangle. Galaxea, J. Coral Reef Stu., 11, 91-100 (2009).

Wan-Lotfi, W.M., A.G. Mazlan, O. Ramlan, C.C. Zaidi and S. Abdullah: Spatial distribution pattern of macrobenthos in East Johor Straits. In: Research and Information Series of Malaysian Coasts $\left(2^{\text {nd }}\right.$ Series): Malaysia Marine Ecosystem: The Studies of Johor Darul Takzim East Coast (Eds.: C.A.R. Mohamed, K.S. Fathul, M.A. Masni and A. Norhayati). Marine Ecosystem Research Centre (EKOMAR), Faculty of Science and Technology, National University of Malaysia (UKM), Bangi, Malaysia, pp. 23-29 (2013).

Yasin, A.H. and S.A. Razak: Distribution of macrobenthos in the South China Sea, area I: Gulf of Thailand and east coast of Peninsular Malaysia. In: Proceedings of the first technical seminar on marine fisheries resources survey in the South China Sea, Area I: Gulf of Thailand and Peninsular Malaysia. SEAFDEC Training Department, Samutprakan, Thailand, pp. 285-293 (1999).

Zhang, S. and S. Zhang: Three species of Siphonalia Adams, 1863 (gastropoda, Buccinidae) from China seas, with descriptions of two new species. J. Oceanol. Limnol., 36, 2333-2336 (2018). 